\title{
Maxillofacial Injuries in Brazilian Children and Adolescents Victims of Physical Violence: A Single Forensic Center Analysis
}

\author{
Alidianne Fábia Cabral Cavalcanti1 ${ }^{\circledR}$, Suellen Rabelo Rocha da Costaํำ, Myroslav Goncharuk- \\ Khomyn $^{3}\left(\mathbb{D}\right.$, Alessandro Leite Cavalcanti ${ }^{10}$
}

${ }^{1}$ Department of Dentistry, State University of Paraíba, Campina Grande, PB, Brazil.

${ }_{2}^{2}$ Private Practice, João Pessoa, PB, Brazil.

${ }^{3}$ Faculty of Dentistry, Uzhhorod National University, Uzhhorod, Ukraine.

Author to whom correspondence should be addressed: Alidianne Fábia Cabral Cavalcanti, Departamento de Odontologia, Centro de Ciências Biológicas e da Saúde, Universidade Estadual da Paraíba, Rua das Baraúnas, S/N, Bodocongó, Campina Grande, PB, Brazil. 58429-500. Phone: +55 83 33153326. E-mail: alidianne.fabia@gmail.com.

Academic Editor: Wilton Wilney Nascimento Padilha

Received: 20 February 2020 / Accepted: 29 June 2020 / Published: 09 July 2020

\footnotetext{
How to cite this article: Cavalcanti AFC, Costa SRR, Goncharuk-Khomyn M, Cavalcanti AL. Maxillofacial injuries in Brazilian children and adolescents victims of physical violence: a single forensic center analysis. Pesqui Bras Odontopediatria Clín Integr. 2020; 20:e5683. https://doi.org/10.1590/pboci.2020.132
}

\begin{abstract}
Objective: To identify the prevalence of maxillofacial injuries resulting from interpersonal violence in Brazilian children and adolescents. Material and Methods: This is a retrospective study conducted at a Center of Forensic Medicine and Forensic Dentistry with a sample of 335 medical reports of victims aged up to 19 years. Variables involved sex and age group, perpetrator, occurrence of the event, characterization of injuries, presence of maxillofacial injuries, type of tissue involvement, and injuries in the oral cavity. Data were analyzed using descriptive, and the Chi-square was used for categorical data. Results: Most victims were female (60.3\%) and aged 15-19 years (57.6\%). Aggressions occurred at home (50.6\%), in the evening $(39.5 \%)$ and involved perpetrators known to the victim (91.5\%). Most victims had multiple injuries (75.8\%), involving up to three regions of the body (93.4\%). Injuries with blunt objects were the most frequent (86.2\%). The prevalence of maxillofacial injuries was $36.7 \%$, with low involvement of the oral cavity (8.4\%). A significant association between the presence of injuries on the face and variables "perpetrator" $(p=0.015)$ and "number of injuries" ( $p=0.006)$ was observed. Conclusion: Female adolescents were the main victims of physical violence, with repercussions in different regions of the body. The prevalence of maxillofacial injuries was high, although with little involvement of oral cavity structures.
\end{abstract}

Keywords: Domestic Violence; Child Abuse; Wounds and Injuries; Maxillofacial Injuries. 


\section{Introduction}

Violence is recognized as a major and growing public health problem for which no country, no city, and no community is immune [1]. Violence corresponds to a common and widespread social phenomenon so that no society is exempt from this practice, especially against its younger members. Worldwide, three out of four small children are regularly submitted to violent discipline by their caregivers [2].

Several characteristics contribute to the increase in statistics on violence against children and adolescents, among which inadequacy of social, economic, health and education policies, leading to living standards based on socioeconomic instability or inequality [3].

Specifically, in Brazil, a recent study showed that social inequities, represented by unequal income distribution, aggravate the occurrence of violence among adolescents [4]. In the period from 2011 to 2017 , 1,460,326 cases of interpersonal or self-harm violence were reported in the Information System for Notifiable Diseases of the Ministry of Health of Brazil (SINAN / MS). Of this total, 219,717 (15.0\%) notifications were against children, and 372,014 (25.5\%) were against adolescents, which represents $40.5 \%$ of cases reported in the system in that period [5].

Children and adolescents victims of violence in the maxillofacial region, most likely, will not forget this episode throughout their lives [6,7]. This can lead to intense suffering and stigmatization, as well as feelings of fear, intimidation, abandonment, invasive behavior, isolation, and social disadvantage [8].

The literature has shown that the prevalence of maxillofacial trauma, resulting from interpersonal violence situations, is high [9,10], and that these occurrences are one of the main etiological factors of injuries and fractures in the facial region $[11,12]$. Head and face are sites commonly involved in cases of traumatic injury, and may or may not be associated with injuries in the other areas of the body, as the violence perpetrator seeks to intimidate and disqualify the victim's identity [13].

In this context, it is understood that the maxillofacial region is a very representative area, since in addition to its relevance from the physiological point of view, its anterior projection, which is usually evidenced without external protections, makes it exposed to aggressions. Therefore, it reaches different levels of severity, including aesthetic, functional and psychosocial damage and permanent deformities and death [12,14-16].

According to the above and considering the relevance of the topic in public health, the present study aimed to identify the prevalence of maxillofacial injuries resulting from episodes of interpersonal aggression in children and adolescents. Additionally, the study sought to characterize the circumstances of the involvement of victims.

\section{Material and Methods}

Study Design and Sample

This is a retrospective study conducted at the Center of Forensic Medicine and Forensic Dentistry (NUMOL) in the municipality of Campina Grande, Brazil, which belongs to the Institute of Scientific Police of the state of Paraíba [17].

In Brazil, people who are victims of physical violence and report the abuse to the police are referred to forensic centers for performing forensic examination [18]. Of the total of 3,854 bodily injury reports recorded in 2015, 797 records were of children and adolescents aged 0-19 years. Inclusion criteria were situations of morbidity related to physical aggression, as defined by World Health Organization International Classification of Disease (ICD10 - Codes X85-Y09) [19]. Inconclusive cases were excluded. Thus, after excluding reports that involved other causes of morbidity, the final sample was composed of 335 reports. 


\section{Data Collection}

A single examiner collected data from June 2018 to June 2019, which were recorded on form adapted from a previous study [20]. The data collection instrument was tested in a pilot study with 35 reports from 2014. Variables included in the study involved the victim's profile (sex and age group), perpetrator, occurrence of the event (place and time of day), characterization of injuries (number of injuries, affected regions and classification), presence of maxillofacial trauma, type of tissue involvement and episodes with repercussions in the oral cavity. The time of occurrence was categorized as follows: morning (06:00-11:59 am), afternoon (12:00-05:59 pm), evening (06:00-1 1:59 pm) and night (00:00-05:59 am).

According to the characterization of the instrument used and the mechanism of injury production, injuries were classified as incision, blunt, incised-stab, firearms injury and chopping wounds. The blunt subtype was categorized into bruise, abrasion, edema, hematoma and fracture. Bruises are characterized by infiltration of extravasated blood into the subcutaneous and/or subepithelial tissues resulting from the rupture of small blood vessels due to application of blunt force. Abrasions are the injuries involving superficial layer of the skin (the epidermis or mucous membrane) due to impact against some hard, blunt and rough object/weapon. Fracture is a complete or incomplete break in the continuity of a bone [21].

\section{Data Analysis}

Data were analyzed with the aid of the Statistical Package for the Social Sciences software (IBM Corp., Armonk, NY, USA), version 21, being presented through descriptive statistics (absolute and percentage distributions, mean and standard deviation). The Chi-square test was used for bivariate analyses. The significance level adopted was $5 \%$.

Ethical Aspects

This study was conducted in compliance with the Declaration of Helsinki and received approval from the Human Research Ethics Committee of the State University of Paraiba (CAAE 0443.0133.000-1 1).

\section{Results}

Most victims were female (60.3\%), ranging from o to 19 years, and average age of 14.0 years $( \pm 4.7$ years). Regarding age group distribution, an increase in the number of cases of aggression was observed with increasing age, with age group from 15 to 19 years being the one with the highest number of occurrences $(57.6 \%)$. Episodes of violence occurred in the home environment (50.6\%), in the evening (39.5\%), causing multiple injuries $(75.8 \%)$, in which the perpetrator was known of the victim $(91.5 \%)$ (Table 1$)$.

Table 1. Distribution of victims according to sex, age group, place and time of occurrence, number of injuries, and perpetrator.

\begin{tabular}{llcc}
\hline \multicolumn{1}{c}{ Variables } & N & \% \\
\hline Sex & & 133 & \\
& Male & 202 & 39.7 \\
\multirow{2}{*}{ Fgemale } & & & 60.3 \\
& 0 to 4 Years & 18 & \\
& 5 to 9 Years & 35 & 5.4 \\
& 10 to 14 Years & 89 & 10.4 \\
15 to 19 Years & 193 & 26.6 \\
& & & 57.6
\end{tabular}




\begin{tabular}{|c|c|c|}
\hline \multicolumn{3}{|l|}{ Place of Occurrence ${ }^{\Psi}$} \\
\hline Residence & 136 & 50.6 \\
\hline School & 31 & 11.5 \\
\hline Sports / Leisure Area & 16 & 5.9 \\
\hline Public Highway & 82 & 30.5 \\
\hline Workplace & 4 & 1.5 \\
\hline \multicolumn{3}{|l|}{ Time of Occurrence ${ }^{\psi}$} \\
\hline Morning & 61 & 19.6 \\
\hline Afternoon & 117 & 37.6 \\
\hline Evening & 123 & 39.5 \\
\hline Night & 10 & 3.2 \\
\hline \multicolumn{3}{|l|}{ Number of Injuries } \\
\hline Single & 83 & 24.8 \\
\hline Multiple & 252 & 75.8 \\
\hline \multicolumn{3}{|l|}{ Perpetrator $^{\Psi}$} \\
\hline Known & 300 & 91.5 \\
\hline Unknown & 28 & 8.5 \\
\hline
\end{tabular}

Regarding the number of injuries, most victims had up to three affected regions of the body (93.4\%), with upper limbs being those with greater involvement (51.3\%), followed by face (43.0\%), lower limbs (23.6\%), chest (18.8\%) and head (13.1\%) (Table 2).

Table 2. Distribution of victims according to the number of affected regions and body regions.

\begin{tabular}{lcc}
\hline \multicolumn{1}{c}{ Variables } & N & \% \\
\hline Number of Affected Regions & & \\
Up to 3 Regions & 313 & 93.4 \\
> 3 Regions & 22 & 6.6 \\
Head & 44 & 13.1 \\
$\quad$ Yes & 291 & 86.9 \\
No & & \\
Face & 144 & 43.0 \\
Yes & 191 & 57.0 \\
No & & \\
Chest & 63 & 18.8 \\
Yes & 272 & 81.2 \\
No & & \\
Upper Limbs & 172 & 51.3 \\
Yes & 163 & 48.7 \\
No & & 23.6 \\
Lower Limbs & 79 & 76.4 \\
Yes & 256 & \\
No &
\end{tabular}

As shown in Table 3, injuries were produced by mechanical agents, with blunt injuries being more frequent $(86.2 \%)$. Regarding the type of blunt injury, abrasions $(57.1 \%)$ and bruises $(40.5 \%)$ were predominant (Table 4). 
Table 3. Distribution of victims according to the classification of the injury.

\begin{tabular}{lcc}
\hline \multicolumn{1}{c}{ Injury Classification* } & N & \% \\
\hline Incision & 9 & 2.7 \\
$\quad$ Yes & 325 & 97.3 \\
No & & \\
Blunt & 288 & 86.2 \\
$\quad$ Yes & 46 & 13.8 \\
$\quad$ No & 3 & \\
Incised-Stab & 331 & 0.9 \\
$\quad$ Yes & & 99.1 \\
$\quad$ No & 18 & 5.4 \\
Firearms Injury & 316 & 94.6 \\
$\quad$ Yes & & 9.3 \\
No & 31 & 90.7 \\
Chopping Wounds & 302 & \\
Yes & & \\
No & & \\
*The victim could have more than one type of injury. &
\end{tabular}

Table 4. Distribution of victims according to the type of blunt injury.

\begin{tabular}{|c|c|c|}
\hline Type of Blunt Injury* & $\mathbf{N}$ & $\%$ \\
\hline \multicolumn{3}{|l|}{ Bruise } \\
\hline Yes & 135 & 40.5 \\
\hline No & 198 & 59.5 \\
\hline \multicolumn{3}{|l|}{ Abrasion } \\
\hline Yes & 190 & 57.1 \\
\hline No & 143 & 42.9 \\
\hline \multicolumn{3}{|l|}{ Edema } \\
\hline Yes & 60 & 18.0 \\
\hline No & 273 & 82.0 \\
\hline \multicolumn{3}{|l|}{ Hematoma } \\
\hline Yes & 19 & 5.7 \\
\hline No & 314 & 94.3 \\
\hline \multicolumn{3}{|l|}{ Bone Fracture } \\
\hline Yes & 8 & 2.4 \\
\hline No & 326 & 97.6 \\
\hline
\end{tabular}

More than one-third of victims exhibited injuries in the maxillofacial region (36.7\%), with a predominance of injuries in soft tissues $(97.6 \%)$. Only $8.4 \%$ had lesions in the oral cavity (Table 5 ).

Table 5. Distribution of victims according to the presence of maxillofacial injury, tissue involvement and injury in the oral cavity.

\begin{tabular}{lcc}
\hline \multicolumn{1}{c}{ Variables } & N & \% \\
\hline Maxillofacial Injury & & \\
Yes & 123 & 36.7 \\
No & 212 & 63.3 \\
Type of Tissue Involvement & & \\
Soft Tissue & 120 & 97.6 \\
Soft and Hard Tissue & 3 & 2.4 \\
Injury in the Oral Cavity & & \\
Yes & 28 & 8.4 \\
No & 307 & 91.6 \\
\hline
\end{tabular}


Table 6 shows a statistically significant association between the presence of facial injury and variables "perpetrator" and "number of injuries". It was also verified that injuries in the head and face regions were present in both sexes, especially in the age group of 15 to 19 years.

Table 6. Association between the presence of head and face injuries, according to the variables sex, age group, perpetrator and number of injuries.

\begin{tabular}{|c|c|c|c|c|c|c|}
\hline \multirow[b]{2}{*}{ Variables } & \multicolumn{3}{|c|}{ Head Injury } & \multicolumn{3}{|c|}{ Face Injury } \\
\hline & $\begin{array}{c}\text { Yes } \\
\text { N (\%) }\end{array}$ & $\begin{array}{c}\text { No } \\
\text { N (\%) }\end{array}$ & p-value & $\begin{array}{c}\text { Yes } \\
\text { N (\%) }\end{array}$ & $\begin{array}{c}\text { No } \\
\text { N (\%) }\end{array}$ & p-value \\
\hline \multicolumn{7}{|l|}{ Sex } \\
\hline Male & $20(15.0)$ & $113(85.0)$ & 0.403 & $58(43.6)$ & $75(56.4)$ & 0.852 \\
\hline Female & $24(11.9)$ & $178(88.1)$ & & $86(42.6)$ & $116(57.4)$ & \\
\hline \multicolumn{7}{|l|}{ Age Group } \\
\hline O to 4 Years & $2(11.1)$ & $16(88.9)$ & 0.768 & $8(44.5)$ & $10(65.7)$ & 0.624 \\
\hline 5 to 9 Years & $5(14.3)$ & $30(85.7)$ & & $12(34.3)$ & $23(65.7)$ & \\
\hline 10 to 14 Years & $9(10.1)$ & $80(89.9)$ & & $42(47.2)$ & $47(52.8)$ & \\
\hline 15 to 19 Years & $28(14.5)$ & $165(85.5)$ & & $82(42.5)$ & $111(57.5)$ & \\
\hline \multicolumn{7}{|l|}{ Perpetrator } \\
\hline Known & $5(17.9)$ & $23(82.1)$ & 0.471 & $6(21.4)$ & $22(78.6)$ & $0.015^{*}$ \\
\hline Unknown & $39(13.0)$ & $261(87.0)$ & & $136(45.4)$ & $164(54.6)$ & \\
\hline \multicolumn{7}{|l|}{ Number of Injuries } \\
\hline Single & $9(10.9)$ & $74(89.1)$ & 0.476 & $25(30.1)$ & $58(69.9)$ & $0.006^{*}$ \\
\hline Multiple & $35(13.9)$ & $217(86.1)$ & & $115(46.4)$ & $133(53.6)$ & \\
\hline
\end{tabular}

*Statistically Significant.

\section{Discussion}

According to the definition of the World Health Organization, violence is characterized by the "the intentional use of physical force or power, threatened or actual, against oneself, another person, a group or a community, which results or is likely to result in injury, death, psychological harm, or developmental loss or damage" [22]. Physical aggression is associated with urban violence and emotional and socioeconomic conflicts, especially among the young population [23].

The total dimension of this phenomenon, as well as its modes of production and its consequences, is challenging to measure, given the diverse nature of epidemiological data produced, but the search for accurate and up-to-date information is essential for understanding the disease and identifying groups of greater vulnerability. In this sense, studies showing relevant information on the victimization profile of children and adolescents victims of violence with repercussions in the maxillofacial region stand out [4,8,9,14,20,24-26].

As reported by Sousa et al. "one way to advance in the understanding of the occurrence of trauma resulting from physical violence is through the analysis of reports issued by medico-legal and forensic service" [27]. Studies in medical-legal and forensic services are very few and can provide important information to guide decision making related to the management and prevention of these injuries [27].

In this study, female victims' predominance was observed, with a sex ratio of 1.5:1. This finding is similar to the results obtained in previous research [20]. Violence perpetrated against adolescents is supported by the asymmetries of power between generations and genders [28]. A previous study showed that adolescent girls aged 11-15 years who had experienced violence had lower expectations of achieving their aspirations than those who had not experienced violence [29].

Physical abuse is inversely proportional to the age of the child [1]. Regarding age, it was found that children were less affected by violence than adolescents, with a progressive increase in the number of cases, so 
that the age group of 15-19 years was the age group that showed the most significant number of victims. Previous authors also described a more frequent pattern of injuries in the group of adolescents [25]. In the literature, there is a divergence in the standardization of age limits for age groups [14], making the comparison of epidemiological studies difficult. In Brazil, for the performance of the forensic examination, referral by the police authority is mandatory after registering a police report. Therefore, for young children, this action depends on a family member or legal guardian. For adolescents, the scenario is different, since they have the autonomy to go to the police station and make the report.

Regarding the place where the aggression occurred, the home was the most frequent. A previous study has demonstrated a statistically significant association between place of occurrence and victim's age [20]. In this investigation, home was the most common place of violence occurrence for age groups of 0-4 years and 5-9 years, whereas, for individuals aged 15-19 years, public roads stood out.

According to the time in which injuries occurred, higher frequency in the evening was observed. This result agrees with previous findings [13] but differs from Cavalcanti [30], who found that most cases of violence occurred in the morning shift. In the morning and afternoon shifts, children and adolescents are generally involved in educational and recreational activities, being inaccessible to aggressors.

Multiple injuries were observed in $75.8 \%$ of victims, being distributed in different regions of the body such as head, face, chest and upper limbs. It is a common finding that when an individual is aggressed for any reason, head and face regions are often involved. Therefore, it is not surprising that in physically abused children, these regions are frequently affected [9,30]. As previously described, injuries to head and face were present in $69.1 \%$ of children and adolescents victims of physical violence [9].

In the present study, face was the body region that showed a large number of injuries, being associated with the number of injuries and the aggression perpetrator. Aggressions in this area are commonly reported by surveys that evaluated reports from forensic institutes [20], as well as by investigations conducted in emergency services [24]. A previous study revealed that victims of physical violence are 2.5 times more likely to have maxillofacial injuries and 2.9 more likely to have oral cavity lesions [20].

Concerning the perpetrator characterization, it was found that a very significant percentage comprised individuals who were part of the social life of children and adolescents, that is, they were known to the victims. However, it was not possible to determine the number of those who had a kinship relationship with aggressed individuals, as there was no information in reports assessed.

All body injuries described in reports of victims of physical aggression were caused by mechanical agents. Mechanical energy can modifying the inertial state of a body, in which injury production can occur through an active, passive, or mixed action, with different results to be observed in the routine of expert examinations [31]. There was a predominance of blunt injuries, with excoriation being the most prevalent subtype, similar to previous results [14].

The prevalence of injuries in the maxillofacial region was high, and a large part of injuries involved only soft tissues, confirming previous findings [14,25,30]. Children who are victims of physical violence may have intra-oral injuries ranging from minor injuries such as bruising on lips to more severe impairments such as dental fractures and in extreme cases, facial fractures [32,33]. The high frequency of soft tissue injuries deserves attention because it may also have negative physical, emotional and functional consequences to the victims [27]. Injuries to the oral cavity affected a small number of individuals, similar to literature findings $[30]$. 
Limitations of using data obtained from the medical record via retrospective review include incomplete or missing data, records lacking specific patient information, and difficulty in interpreting or verifying documented information [34,35]. Additionally, the study was conducted at a forensic medicine institute, not including more severe cases of violence that led victims to seek hospital care. Despite these limitations, this study fills an important gap in the literature on violence against children and adolescents. To ensure an accurate and complete report of this observational study, the Strengthening the Reporting of Observational Studies in Epidemiology (STROBE) Statement was followed [36].

The impact on victims' life experience and emotional development must be highlighted since many of these aggressions against children and adolescents remain unreported [25]. Besides, the potential influence of these experiences on the behavior of these individuals in adulthood should be highlighted, who can shift from victims to aggressors, perpetuating a cycle of violence.

Epidemiological research seeks to understand the multifactorial aspects of oral and maxillofacial injuries to determine types of injury, risk groups, more frequent causes, needs of health care facilities, and specific training of human resources and development of prevention programs. Therefore, these findings can help formulate and implement local policies to reduce the consequences of physical violence against children and adolescents.

\section{Conclusion}

Female adolescents were the main victims of physical aggression, with repercussions in different regions of the body. The prevalence of maxillofacial lesions was high, although there was little involvement of oral cavity structures.

\section{Authors' Contributions}

AFFC (D) 0000-0002-7779-2478 $\begin{aligned} & \text { Conceptualization, Methodology, Validation, Formal Analysis, Writing - Original } \\ & \text { Draft Preparation, Writing - Review and Editing and Project Administration. }\end{aligned}$
$\begin{array}{lll}\text { SRRC } & \text { (D) 0000-0003-0841-2061 } & \text { Investigation, Data Curation and Writing - Original Draft Preparation. } \\ \text { MGK } & \text { (D) 0000-0002-7482-3881 } & \text { Formal Analysis and Writing - Review and Editing. } \\ \text { ALC } & \text { (D) } 0000-0003-3572-3332 & \text { Methodology, Formal Analysis and Writing - Review and Editing. }\end{array}$
$\begin{array}{ll}\text { All authors declare that they contributed to critical review of intellectual content and approval of the final version to be } \\ \text { published. }\end{array}$

\section{Financial Support}

Brazilian National Council for Scientific and Technological Development (CNPq), Fellowship of Research Productivity (Process No. 305332/2019-8).

\section{Conflict of Interest}

The authors declare no conflicts of interest.

\section{References}

[1] Güngör HC. Hidden behind dental trauma: child physical abuse? Pesqui Bras Odontopediatria Clin Integr 2018; 18(1):e3869. https://doi.org/10.4034/PBOCI.2018.181.ed2

[2] United Nations Children's Fund (UNICEF). A familiar face - violence in the lives of children and adolescents. Available from: https://data.unicef.org/resources/a-familiar-face/\#. [Accessed on January 28, 2020].

[3] World Health Organization. Child maltreatment. Available from: http://www.who.int/mediacentre/factsheets/fs150/en/. [Accessed on November 10, 2019]. 
[4] Silva AN, Marques ES, Silva LS, Azeredo CM. Wealth inequalities in different types of violence among Brazilian adolescents: national survey of school health 2015. J Interpers Violence 2019; 2019:886260519888184. https://doi.org/10.1177/0886260519888184

[5] Brasil. Secretaria de Vigilância em Saúde. Ministério da Saúde. Boletim Epidemiológico número 27. Análise epidemiológica da violência sexual contra crianças e adolescentes no Brasil, 2011 a 2017. Brasília: Ministério da Saúde; 2018. [In Portuguese]

[6] Cavalcanti AL, Melo TR. Facial and oral injuries in Brazilian children aged 5-17 years: 5-year review. Eur Arch Paediatr Dent 2008; 9(2):102-4.

[7] Cavalcanti AL, Alencar CRB, Rodrigues ISA, Pinto MSA, Xavier AFC, Cavalcanti CL, Valença AMG. Injuries to the head and face in Brazilian adolescents and teenagers victims of non-natural deaths. J Forensic Odonto-Stomatology 2012; 30(1):13-21.

[8] Ítalo de Macedo Bernardino IM, Nóbrega LM, Silva JRC, Alencar CRB, Olinda RA, d'Ávila S. Social determinants of health and maxillofacial injuries in children and adolescents victims of violence: a novel GIS-based modelling application. Int J Paediatr Dent 2019; 29(3):375-83. https://doi.org/10.1111/ipd.12461

[9] Cavalcanti AL. Prevalence and characteristics of injuries to the head and orofacial region in physically abused children and adolescents - a retrospective study in a city of the Northeast of Brazil. Dent Traumatol 2010; 26(2):14953. https://doi.org/10.1111/j.1600-9657.2009.00859.x

[10] Barbosa KGN, Bernardino IM, Cavalcante GMS, Ferreira e Ferreira E, Martins RC, d'Avila S. Patterns of oralmaxillofacial trauma and determinant factors among Brazilian victims of physical aggression: a 4-year study. Oral Health Prev Dent 2018; 16(6):483-9. https://doi.org/10.3290/j.ohpd.a41545

[11] Tent PA, Juncar RI, Lung T, Juncar M. Midfacial fractures: a retrospective etiological study over a 10-year period in Western Romanian population. Niger J Clin Pract 2018; 21(12):1570-5. https://doi.org/10.4103/njcp.njcp_256_18

[12] Vieira CL, Araújo DCC, Ribeiro MLS, Laureano Filho JR. Soft tissue injury in victims of bucco-maxillo-facial trauma. Rev Cir Traumatol Buco-Maxilo-Fac 2013; 13(1):89-96.

[13] Silva CJP, Ferreira RC, Paula LPP, Haddad JPA, Moura AM, Naves MD, et al. Maxillofacial injuries as markers of urban violencea comparative analysis between the genders. Cienc Saude Coletiva 2014; 19(1):127-36. https://doi.org/10.1590/1413-81232014191.205

[14] Bregagnolo LA, Bregagnolo JC, Silveira F, Bergamo AL, Santi LN, Watanabe MGC. Oral and maxillofacial trauma in Brazilian children and adolescents. Braz Dent J 2013; 24(4):397-401. https://doi.org/10.1590/0103-6440201302227

[15] Moura LB, Blasco MAP, Torriani MA. A 10-year retrospective analysis of maxillofacial trauma in Pelotas-RS. Rev Cir Traumatol Buco-Maxilo-Fac 2018; 18(1):6-11.

[16] Scannavino FLF, Santos FS, Novo Neto JP, Novo LP. Epidemiological analysis of maxillofacial trauma of an emergency service. Rev Cir Traumatol Buco-Maxilo-Fac 2013; 13(4):95-100.

[17] Paraíba. Secretaria de Segurança e Defesa Social. Instituto de Polícia Científica do Estado da Paraíba. Núcleo de Medicina e Odontologia Legal. Available from: http://www.ipcpb.com.br/sites/contatos. [Accessed on October 9, 2019]. [In Portuguese]

[18] Brasil. Decreto Lei no 3689. Código do Processo Penal. Brasília: Brasil; 1941. [In Portuguese]

[19] World Health Organization. International Statistical Classification of Diseases and Related Health Problems 10th Revision. Available from: https://icd.who.int/browse10/2019/en. [Accessed on January 18, 2020].

[20] Oliveira TBS, Pinto MSA, Macedo RF, Oliveira TSB, Cavalcanti AL. Characterization of morbidity from interpersonal violence in brazilian children and adolescents. Iran J Public Health 2014; 43(9):1184-91.

[21] Vij K. Textbook of Forensic Medicine and Toxicology. 5th. ed. New Delhi: Elsevier; 2011. 593p.

[22] World Health Organization. Global consultation on violence and health. violence: a public health priority. Geneva: WHO; 1996 (document WHO/EHA/ SPI.POA.2).

[23] Miguens-Jr SAQ, Borges TS, Dietrich LAB, Oliveira MC, Hernandez PAG, Kramer PF. A retrospective study of oral and maxillofacial injuries in an emergency hospital in Southern Brazil. Braz Res Pediatr Dent Integr Clin 2016; 16(1):339-50. https://doi.org/10.4034/PBOCI.2016.161.36

[24] Laureano ICC; Farias L, Alencar GSA, Cavalcanti AFC, Alencar CRB, Cavalcanti AL. Injuries in the maxillofacial complex and associated factors in brazilian victims of violence: a cross-sectional study. Cum Dent J 2019; 22(1):1-8. https://doi.org/10.7126/cumudj.467382

[25] Silva CJP, Ferreira e Ferreira E, Paula LPP, Naves MD, Vargas AMD, Zarzar PMPA. The urban violence against children and adolescents in Belo Horizonte: a story told through the maxillofacial traumas. Physis 2011; 21(3):110320. https://doi.org/10.1590/So103-73312011000300018

[26] Cavalcanti AL, de Alencar CRB. Injuries to the head and face in 0-4-year-old child victims of fatal external causes in Campina Grande, PB, Brazil. Turkish J Pediatrics 2010; 52(6):612-7.

[27] Sousa RIM, Bernardino IM, Castro RD, Cavalcanti AL, Bento PM, D’Ávila S. Maxillofacial trauma resulting from physical violence against older adults: a 4-year study in a brazilian forensic service. Braz Res Pediatr Dent Integr Clin 2016; 16(1):313-22. https://doi.org/10.4034/PBOCI.2016.161.33

[28] Gessner R, Fonseca RMGS, Oliveira RNG. Violence against adolescents: an analysis based on the categories gender and generation. Rev Esc Enferm 2014; 48(spe):102-8. 
[29] Kabiru CW, Mumah JN, Maina BW, Abuya BA. Violence victimisation and aspirations-expectations disjunction among adolescent girls in urban Kenya. Int $J$ Adolesc Youth 2017; 23(3):281-90. https://doi.org/10.1080/02673843.2017.1345769

[30] Cavalcanti AL. Maxillo facial injuries in victims of violence at school environment. Cien Saude Colet 2009; 14(5):1835-42.

[31] França GV. Medicina Legal. 9th. ed. Rio de Janeiro: Guanabara-Koogan; 2011. [In Portuguese]

[32] Cavalcanti AL, Santos JA, Xavier AFC, Temóteo LM, Paiva SM. Head and face injuries in Brazilian schoolchildren victims of physical bullying: a population-based study. Braz Res Pediatr Dent Integr Clin 2015; 15(1):451-9. https://doi.org/10.4034/PBOCI.2015.151.47

[33] Oral health of children and adolescents victims of maltreatment housed in foster care: a case-control study. Braz Res Pediatr Dent Integr Clin 2016; 16(1):279-87. https://doi.org/10.4034/PBOCI.2016.161.29

[34] Gregory KE, Radovinsky L. Research strategies that result in optimal data collection from the patient medical record. Appl Nurs Res 2012; 25(2):108-16. https://doi.org/10.1016/j.apnr.2010.02.004

[35] Gearing RE, Mian IA, Barber J, Ickowicz A. A methodology for conducting retrospective chart review research in child and adolescent psychiatry. J Can Acad Child Adolesc Psychiatry 2006; 15(3):126-34.

[36] von Elm E, Altman DG, Egger M, Pocock SJ, Gøtzsche PC, Vandenbroucke JP, STROBE Initiative. Strengthening the Reporting of Observational Studies in Epidemiology (STROBE) statement: guidelines for reporting observational studies. BMJ 2007; 335(7624):806-8. https://doi.org/10.1136/bmj.39335.541782.AD 